\title{
UNILATERAL PULMONARY OEDEMA: A CASE REPORT
}

\author{
Patrick W. Knapp and Joseph L. Seltzer
}

Pulmonary oedema is known to occur secondary to a high negative intrathoracic pressure. ${ }^{1-5}$ We present a case of unilateral pulmonary oedema which we feel was caused by obstruction of the main bronchus in a spontaneously breathing patient.

\section{REPORT OF A CASE}

A 65-year-old white male with squamous cell carcinoma of the larynx was scheduled for a total laryngectomy and radical neck dissection. He had a history of a myocardial infarction complicated by congestive heart failure seven years before admission. He was a 50 pack-year cigarette smoker and became short of breath with minimal exertion. His only medication was digoxin 0.25 mg per day.

Physical examination revealed an elderly man with a barrel chest and increased resonance with decreased breath sounds bilaterally. The first and second heart sounds were regular and distant. and no $S_{3}, S_{4}$ or murmur were audible. No jugular vein distension or peripheral oedema was noted.

An electrocardiogram showed evidence of an anterior wall infarction and elevated ST segment which persisted on serial cardiograms, suggesting a ventricular aneurysm. The preoperative chest $X$-ray showed an enlarged left ventricle without cardiomegaly, increased interstitial markings bilaterally, and evidence of pulmonary hypertension. Arterial blood gases breathing room air were $\mathrm{Pa}_{\mathrm{O}_{2}} 10.37 \mathrm{kPa}(78 \mathrm{~mm} \mathrm{Hg}), \mathrm{Pa}_{\mathrm{CO}_{2}} 4.52 \mathrm{kPa}$ (34 $\mathrm{mm} \mathrm{Hg}$ ), and $\mathrm{cH}^{+} 38.90 \mathrm{nmol} / \mathrm{l}(\mathrm{pH} 7.41)$. Pulmonary function tests showed a vital capacity of two litres with a predicted value of 3.9 litres and $\mathrm{FEV}_{t} / \mathrm{VC}$ was $\mathbf{0 . 6 1}$.

It was elected to do a tracheostomy under local anaesthesia because of possible airway obstruction by the tumour. An $8.0 \mathrm{~mm}$ Rusch anode tube was inserted between the second and third tracheal rings. Breath sounds were equal bilaterally. The tube was secured by two sutures placed

Patrick W. Knapp, M.D., Resident in Anesthesiology; Joseph L. Seltzer, M.D., Assistant Professor. Department of Anesthesiology. State University of New York, Upstate Medical Center, Syracuse, New York, 13210.

Canad. Anaesth. Soc. J., vol. 26, no. 5, September 1979 along the clayicle. An arterial catheter was placed to monitor blood gases. Induction proceeded with thiopentone and anaesthesia was maintained with meperidine. metocurine and 66 per cent nitrous oxide with oxygen. Controlled ventilation was commenced with a volume of $750 \mathrm{ml}$ at a rate of 10 per minute. Arterial blood gases one hour after induction was $\mathrm{Pa}_{\mathrm{O}_{2}} 9.17 \mathrm{kPa}(68.6 \mathrm{~mm} \mathrm{Hg})$, $\mathrm{Pa}_{\mathrm{CO}_{2}} 4.99 \mathrm{kPa}\left(37.5 \mathrm{~mm} \mathrm{Hg}\right.$ ), and $\mathrm{CH}^{+} 38.02$ $\mathrm{nmol} / \mathrm{l}$ ( $\mathrm{pH} 7.42$ ). Auscultation of the chest again revealed breath sounds which were equal bilaterally. $\mathrm{FI}_{\mathrm{O}_{2}}$ was increased to 0.5 . Repeated blood gas analysis showed the $\mathrm{Pa}_{\mathrm{O}_{2}}$ had increased to $18.75 \mathrm{kPa}(141 \mathrm{~mm} \mathrm{Hg})$. Several subsequent examinations of the lungs revealed no changes and the remainder of the anaesthetic was uneventful. During the five-hour operation he received $1850 \mathrm{ml}$ of crystaloid solution $500 \mathrm{ml}$ of colloid and $500 \mathrm{ml}$ of whole blood. Muscle relaxation was reversed with neostigmine $2.5 \mathrm{mg}$ and atropine $1.2 \mathrm{mg}$. Although no measurements were made, respirations were judged to be adequate and the patient was taken to the recovery room. Fifteen minutes after arrival he became acutely agitated, dyspnoeic and cyanotic. Physical examination of the chest revealed normal breath sounds and increased resonance on the left side and no breath sounds with dullness to percussion on the right. Assisted ventilation was begun. Based on the clinical findings, which indicated a total lack of ventilation of the right side of the chest, the tracheal tube was withdrawn until the cuff was in view at the stoma. This manoeuvre resulted in a rapid improvement in the patient's colour and a return of bilateral ventilation. Coarse rales were now heard in the right lung. A chest $X$-ray following this episode showed pulmonary oedema confined to the right lung field (Figure 1).

The patient was taken to the intensive care unit and continued on mechanical ventilation with $V_{R}$ 800, IMV 10 and PEEP $3 \mathrm{~cm} \mathrm{H}_{2} \mathrm{O}$. Four hours later a chest $\mathrm{X}$-ray showed less fluid on the right side and arterial blood gases on $\mathrm{F}_{\mathrm{I}_{2}}$ of 0.5 were $\mathrm{Pa}_{\mathrm{O}_{2}} 11.92 \mathrm{kPa}(91 \mathrm{~mm} \mathrm{Hg}), \mathrm{Pa}_{\mathrm{CO}_{2}} 5.05 \mathrm{kPa}$ (38 $\mathrm{mm} \mathrm{Hg}$ ), and $\mathrm{cH}^{+} 40.74 \mathrm{nmol} / 1$ (pH 7.39). The next morning, a chest $X$-ray showed almost total clearing of the right-sided infiltrate (Figure 2) and 


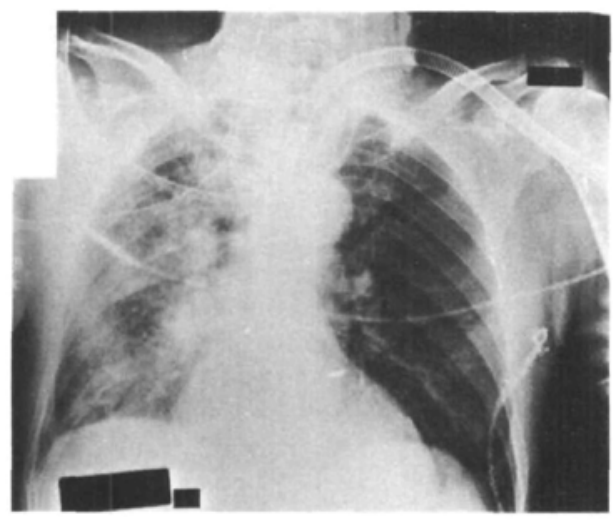

Figure 1 The chest $X$-ray obtained in the recovery room shows a generalized hazy density in the right lung.

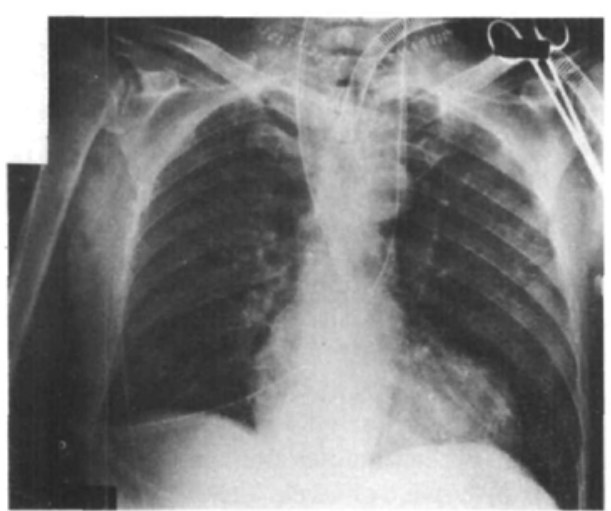

FIGURE 2 The morning of the first postoperative day there had been good resolution of the densities seen on the chest film taken in the recovery room.

arterial blood gases when breathing 40 per cent oxygen through a treacheostomy collar were $\mathrm{Pa}_{\mathrm{O}_{2}} 27,82 \mathrm{kPa}(134 \mathrm{~mm} \mathrm{Hg}), \mathrm{Pa}_{\mathrm{CO}_{2}} 5.29 \mathrm{kPa}$ (39 $\mathrm{mm} \mathrm{Hg}$ ), and $\mathrm{cH}^{+} 37.15 \mathrm{nmol} / \mathrm{l}(\mathrm{pH} 7.43)$. The patient was confused for several days but eventually returned to his pre-operative level of consciousness and was discharged to home on the ISth postoperative day.

\section{Discussion}

Our patient had several conditions which predisposed him to develop pulmonary oedema. He had chronic lung disease and pulmonary hypertension, a history of previous myocardial infarction and congestive heart failure. In addition, he was anesthetized by a technique that might have mild negative inotropic action and had received $2850 \mathrm{ml}$ of fluid during operation. However, the oedema was limited to one lung and did not develop until after the patient had been breathing spontaneously for several minutes. Based on the sequence of events and the physical examination in the recovery room. it would appear that his inspiratory effort caused the tracheal tube to move to a position which effectively blocked the right main bronchus. The resulting high negative pressure in the right hemi-thorax with his vigorous inspiratory efforts resulted in the development of pulmonary oedema in that obstructed lung.

This complication probably could have been avoided by better management of the tracheal tube placement. Since we do not have an explanation for the hypoxia during operation it is possible that the tip of the tube was near the carina throughout the procedure. As the head and neck were repositioned during the operation the fixation points, which were far from the trachostomy stoma, allowed intermittent movement of the tube. When the patient began to breathe spontaneously, his inspiratory effort moved the tube so that the right main bronchus became obstructed. We suggest that tracheal tubes introduced through a tracheostomy during operation should be securely fixed at a proper length and changed to a standard laryngectomy tube before the patient is transferred from the care of the anaesthetist.

\section{SUMMARY}

We have presented a case of unilateral pulmonary oedema which we feel is secondary to obstruction of the right main bronchus during spontaneous respiration. An anode tracheal tube was introduced through a tracheostomy during operation in a man with pre-existing pulmonary and cardiac disease. At the end of the anaesthetic, acute obstruction to ventilation of the right main bronchus developed with the tube still in place and the patient breathing spontaneously. The obstruction was relieved, by repositioning of the tracheal tube, but not before the patient developed right unilateral pulmonary oedema.

\section{RÉSUMÉ}

Une sonde trachéale métallisée fut introduite par trachéotomie chez un vieillard atteint de maladies cardiaque et pulmonaire. A la fin de l'anesthésie, une obstruction aigue de la bronche souche droite s'est produite alors que le malade respirait spontanément. Le retrait de la sonde a 
permis de corriger l'obstruction mais le malade était déjà en crise d'œdème aigu du poumon droit seul. En étudiant la séquence des évènements et parce que l'eedème se limitait à un seul poumon. les auteurs concluent que la caurse en était l'obstruction d'une bronche souche.

\section{REFERENCES}

1. Oswalt, C.E.. Gates, G.A. \& Holstrom. F.M.G. Pulmonary edema as a complication of acute airway obstruction. J.A.M.A. 238: 1833 (1977).

2. HURBert. B.J. Acute airway obstruction and pulmonary edema (letter). J.A.M.A. 239: 1281 (1978).

3. Wagarudoin. M. \& Berstein. A. Reexpansion pulmunary edema. Thorax 30: 54 (1975).

4. Travis. K.W. Todres. I.D. \& Shannon, D.C. Pulmonary edema associated with croup and epiglottitis. Pediatrics 59: 695 (1977).

5. Calenoff, L., Kruglick, G.D. \& Woudruff, A. Unilateral pulmonary edema. Radiology 126:19 (1978). 